\title{
Pengaruh PMR (Progressive Muscle Relaxation) Terhadap Insomnia Pada Lansia Di Panti Sosial Lanjut Usia Tresna Werdha Natar Provinsi Lampung Tahun 2012
}

\author{
Andi Thahir \\ Dosen Fakultas Tarbiyah dan Keguruan, IAIN Raden Intan Lampung
}

Diterima: 13 Februari 2014. Disetujui: 12 April 2014. Dipublikasikan: Juni 2014

\begin{abstract}
Abstrak : Gangguan tidur juga dikenal sebagai penyebab morbiditas yang signifikan. Ada beberapa dampak yang serius terhadap gangguan tidur pada lansia. Penelitian ini bertujuan untuk mengetahui pengaruh PMR (Progressive Muscle Relaxation) terhadap insomnia pada lansia Di Panti Sosial Lanjut Usia Tresna Werdha Natar Provinsi Lampung Tahun 2012. Metode penelitian yang digunakan quasi eksperimen dengan pendekatan Pre Post Test Control Group. Populasi sampel yang diambil pada penelitian ini yaitu 50 responden di bagi menjadi dua kelompok yaitu intervensi dan kontrol. Penelitian ini menggunakan analisa uji $t$ (paired t test). Hasil penelitian ini yaitu terdapat pengaruh pengaruh PMR (Progressive Muscle Relaxation) terhadap insomnia pada lansia di panti sosial lanjut usia Tresna Werdha Natar Provinsi Lampung.
\end{abstract}

Kata kunci: Progressive Muscle Relaxation, Insomnia, Lansia

\section{Pendahuluan}

Usia harapan hidup antara penduduk negara maju dengan negara sedang berkembang atau terbelakang, apabila kita perhatikan tampak perbedaan yang nyata. Penduduk di negara maju mempunyai usia harapan hidup yang lebih panjang dibandingkan dengan negara yang sedang berkembang, apalagi terbelakang. Perbandingan berdasarkan jenis kelamin juga menunjukkan usia harapan hidup masyarakat negara maju, lebih tinggi dari pada negara sedang berkembang atau negara miskin. Laporan WHO tahun 2006 menunjukkan usia harapan hidup wanita di Swiss pada tahun 2004 mencapai 83 tahun, sedangkan prianya 78 tahun. Di Amerika Serikat, pada tahun 2004 usia harapan hidup wanita mencapai 80 tahun, dan pria mencapai 75 tahun. Wanita Jepang mencapai 86 tahun, dan pria 79 tahun. Wanita Malaysia dan Vietnam hanya mencapai 74 tahun, dan prianya hanya 69 tahun, sedangkan orang Indonesia lebih pendek lagi, yaitu wanita hanya mencapai 68 tahun, dan pria hanya 65 tahun (Pangkahila, 2007).

Hal tersebut didukung juga oleh pendapat dari Menteri Kordinator Kesejahteraan Rakyat (Menkokesra) pada tahun 2009, Indonesia termasuk negara yang memasuki era penduduk berstruktur lanjut usia, karena jumlah penduduk yang berusia 60 tahun keatas sekitar 7,18\%. Peningkatan jumlah penduduk lansia ini antara lain disebabkan karena tingkat sosial ekonomi masyarakat yang meningkat, kemajuan dalam bidang pelayanan kesehatan, dan tingkat pengetahuan masyarakat yang meningkat. Jumlah penduduk lansia pada tahun 2006 sebesar kurang lebih 19 juta, usia harapan hidup 66,2 tahun, pada tahun 2010 ini diperkirakan sebesar 23,9 juta (9,77\%), usia harapan hidupnya 67,4 tahun dan pada tahun 2020 diperkirakan sebesar 28,8 juta (11,34\%), dengan usia harapan hidup 71,1 tahun (Purwanto, 2007).

Berdasarkan data di atas, meningkatnya usia harapan hidup penduduk Indonesia membawa konsekuensi bertambahnya jumlah lansia. Peningkatan usia lanjut akan berpengaruh pada berbagai aspek kehidupannya (fisik, mental, dan ekonomi). Mengantisipasi hal ini maka pengkajian masalah-masalah usia lanjut perlu ditingkatkan, termasuk aspek keperawatannya, agar dapat menyesuaikan dengan kebutuhan serta menjamin tercapainya usia lanjut yang bahagia, berdaya guna dalam kehidupan keluarga, dan masyarakat Indonesia (Tamher, 2009).

Selain itu juga bila seseorang bertambah tua maka kemampuan fisik dan psikisnya 
perlahan- lahan akan mengalami penurunan. Salah satu contohnya yaitu lansia akan mengalami gangguan pemenuhan kebutuhan tidur. Gangguan tidur pada lanjut usia merupakan keadaan dimana seseorang mengalami suatu perubahan dalam kuantitas dan kualitas pola istirahatnya yang menyebabkan rasa tidak nyaman atau mengganggu gaya hidup yang diinginkan (Eka, 2009). Lansia lebih sering mengalami gangguan tidur dikarenakan semakin bertambah umur seseorang maka akan mengalami penurunan fungsi organ yang berpengaruh pada kondisi mental dan psikososial seperti kurang percaya diri, cemas, stress, dan depresi. Hal inilah yang memicu mengapa sebagian besar lansia mengalami gangguan pola tidur (Rafli, 2004).

Gangguan tidur juga dikenal sebagai penyebab morbiditas yang signifikan. Ada beberapa dampak yang serius terhadap gangguan tidur pada lansia misalnya mengantuk berlebihan di siang hari, gangguan atensi dan memori, mood, depresi, sering terjatuh, penggunaan hipnotik yang tidak semestinya, dan penurunan kualitas hidup. Prevalensi gangguan tidur pada lansia cukup tinggi yaitu sekitar $67 \%$. Walaupun demikian, hanya satu dari delapan kasus yang menyatakan bahwa gangguan tidur telah didiagnosis oleh dokter (Amir, 2007).

Berdasarkan penelitian terhadap kelompok anak-anak muda di Denpasar menunjukkan 30-40 persen aktivitas mereka untuk tidur. Dalam jajak pendapat yang dilakukan Galup terhadap orang dewasa di Amerika menyebutkan bahwa $49 \%$ menderita gangguan insomnia dan beberapa gangguan lain yang berkaitan dengan tidur. Sedangkan penelitian yang dilakukan di Jepang disebutkan 29\% responden tidur kurang dari 6 Jam, 23\% merasa kekurangan dalam jam tidur, $6 \%$ menggunakan obat tidur, kemudian $21 \%$ memiliki prevalensi insomnia dan $15 \%$ kondisi mengantuk yang parah pada siang harinya (Purwanto, 2007). Salah satu bentuk dari terapi perilaku terhadap penurunan insomnia adalah dengan teknik relaksasi. Teknik relaksasi pertama kali dikenalkan oleh Edmund Jacobson seorang Psikolog dari Chicago yang mengembangkan metode fisiologis melawan ketegangan dan kecemasaan. Metode relaksasi terdiri dari beberapa macam, yaitu: (1) relaksasi otot, (2) pernafasan diafragma, (3) imagery training, (4) biofeedback, dan (5) hipnosis (Miltenberger, 2004). Relaksasi otot progresif sampai saat ini menjadi metode relaksasi termurah, tidak memerlukan imajinasi, tidak ada efek samping, mudah untuk dilakukan, serta dapat membuat tubuh dan fikiran terasa tenang, rileks, dan lebih mudah untuk tidur (Davis dalam Ari, 2010).

Adapun yang menjadi penelitian terkait dari penelitian ini yaitu telah dilakukan oleh Supriati (2010) yang menyimpulkan bahwa kunci untuk memicu respons relaksasi dengan cara ini adalah untuk mengambil alih dari otot-otot menegang sukarela oleh mereka dan memaksa mereka ke dalam keadaan relaksasi. Setelah otot-otot rileks maka komponen lain dari respons relaksasi secara alami akan mengikuti. Otot-otot rileks membutuhkan oksigen lebih sedikit sehingga pola pernapasan lambat dan memperdalam. Jantung tidak perlu mengalahkan begitu cepat untuk membawa oksigen ke otot-otot tegang. Denyut jantung dan penurunan tekanan darah.

Berdasarkan hasil studi pendahuluan yang dilakukan oleh peneliti pada awal bulan Maret 2012 di Panti Sosial Lanjut Usia Tresna Werdha Natar, didapatkan hasil bahwa terdapat 103 lansia yang aktif ikut serta dalam kegiatan pemeriksaan kesehatan. Dari hasil wawancara dengan petugas kesehatan, lansia sering mengeluh pusing dan lemas. Hasil wawancara dari 30 lansia yang ikut dalam posyandu lansia tersebut 16 diantaranya mengeluh mengalami gangguan untuk memulai tidur pada malam hari. Dalam semalam hanya tidur 2 sampai 3 jam saja. Lansia mengeluhkan lebih cepat lelah dan badannya lemah. Upaya yang sudah dilakukan oleh petugas kesehatan dalam posyandu lansia tersebut dalam menangani masalah ini adalah dengan memberikan obat tidur, sedangkan pemberian obat tidur dalam waktu yang lama dapat mengakibatkan efek yang tidak baik untuk kesehatan. Berdasarkan studi di atas penting untuk diteliti tentang teknik relaksasi otot progresif untuk mengetahui sejauh mana pengaruhnya 
terhadap perubahan insomnia pada lanjut usia.

Berdasarkan latar belakang di atas, maka peneliti tertarik untuk mengambil penelitian mengenai "Pengaruh PMR (Progressive Muscle Relaxation) Terhadap Insomnia Pada Lansia Di Panti Sosial Lanjut Usia Tresna Werdha Natar Provinsi Lampung Tahun 2012”, untuk diteliti lebih lanjut.

\section{Insomnia}

\section{Pengertian}

Gangguan tidur/Insomnia didefinisikan sebagai suatu kehilangan tidur secara temporer atau kronis (Goldenson). Insomnia adalah suatu kondisi ketidakpuasan seseorang dalam hal kuantitas atau kualitas tidurnya dan berlangsung selama beberapa waktu (WHO, 2002). Kurangnya waktu tidur dari kriteria normal, sebaiknya tidak digunakan dalam mendiagnosa insomnia karena beberapa individu mempunyai jam tidur yang sedikit tetapi tidak mempunyai keluhan insomnia dan sering disebut short sleeper. Sebaliknya ada orang yang merasa kurang tidur padahal jumlah jam tidurnya masih dalam batas normal sehingga memerlukan tidur lebih lama. Orang yang membutuhkan waktu tidur lebih dari 8 jam disebut long sleeper (Kaplan et.al, 2005).

Insomnia adalah ketidakmampuan penderita untuk memperoleh jumlah tidur yang diperlukan agar dapat menjalankan fungsi pada siang hari secara efisien(Berrios). Penderita insomnia pada dasarnya hanya punya dua keluhan utama, dimana seseorang sulit masuk tidur dan sulit mempertahankan tidur(Hartmann). Insomnia dapat didefinisikan sebagai suatu keadaan dimana seseorang sulit masuk tidur atau kesulitan mempertahankan tidur dalam kurun waktu tertentu sehingga menimbulkan penderitaan atau gangguan dalam berbagai fungsi sosial, pekerjaan ataupun fungsi-fungsi kehidupan lainnya (Erry, 2008).

Kesulitan tidur atau insomnia adalah keluhan tentang kurangnya kualitas tidur yang disebabkan oleh satu dari; sulit memasuki tidur, sering terbangun malam kemudian kesulitan untuk kembali tidur, bangun terlalu pagi, dan tidur yang tidak nyenyak. Insomnia tidak disebabkan oleh sedikitnya seseorang tidur, karena setiap orang memiliki jumlah jam tidur sendiri-sendiri. Tapi yang menjadi penekanan adalah akibat yang ditimbulkan oleh kurangnya tidur pada malam hari seperti kelelahan, kurang gairah, dan kesulitan berkonsentrasi ketika beraktivitas.

2. Penggolongan Insomnia

Sebagian besar insomnia terbagi menjadi dua macam yaitu insomnia primer dan insomnia sekunder (Bastaman, 2008).

a) Insomnia Primer, orang-orang yang termasuk golongan insomnia primer tercakup dalam kelompok yang khas. Mereka tidak neurotik dan tampak sehat. Prinsipnya mereka tidak menikmati tidur meskipun sebenarnya mereka dapat tidur sampai mendengkur. Tidak dapat menikmati tidur dapat disamakan dengan tidur tanpa mengalaminya. Insomnia primer primer dapat ditegakkkan bila tidak berhubungan dengan gangguan mental organik. Pada umumnya insomnia primer mempunyai masa latensi tidur yang panjang,efisiensi tidur yang rendah dan tipe ini sangat jarang.

b) Insomnia Sekunder, jenis insomnia ini banyak dijumpai pada penderita kelainan jiwa seperti psikoneurotik. Penderita psikoneurotik mempunyai keluhan insomnia, tidurnya terganggu oleh banyak mimpi yang berlangsung dari saat mulai tidur sampai bangun. Pola mimpi mereka hampir sama misalnys berjumpa dengan orang yang sudah meninggal, jatuh dari tempat yang tinggi, dikejar oleh orang-orang jahat dan binatang yang mengerikan. Oleh karena tidur mereka disertai mimpi yang seram (pavor nocturnes), maka pada keesokan harinya pada waktu bangun tidur mereka akan merasakan keletihan dan kebugaran tubuhnya berkurang. Insomnia sekunder ini merupakan suatu keadaan insomnia yang berhubungan dengan gangguan mental atau faktor- faktor organik yang bermakna. WHO memasukkan insomnia kedalam golongan 
Disorder of Initiating and Maintining Sleeps (DIMS) dan membagi insomnia menjadi tiga golongan besar sebagai berikut :

c) Transient insomnia, penderita transient insomnia biasanya termasuk orang yang tidur secara normal tetapi karena dikarenakan suatu stress yang berlangsung dalam waktu yang tidak terlalu lama, misalnya perjalanan jauh dengan kapal terbang yang melampui zona waktu , maka hospitalisasi mereka menjadi tidak bisa tidur

d) Short term insomnia, penderita short insomnia mengalami stress situasional, misalnya kehilangan atau kematian seseorang yang dekat, perubahan pekerjaan dan penyakit fisik. Biasanya penderita insomnia golongan ini diderita tiga minggu dan akan pulih seperti biasa.

e) Long term insomnia, long term insomnia adalah insomnia kronik. Insomnia ini dapat berlangsung dalam waktu berbulan-bulan sampai bertahun-tahun dan perlu diobati dengan tehnik tertentu natau dengan obat- obatan yang sesuai dengan gangguan utama yang diderita pasien.

3. Gejala-gejala Insomnia

Menurut Budiman (2009) ada 4 gangguan insomnia, yaitu :

a) Initial Insomnia Initial insomnia adalah kesulitan untuk memulai tidur

b) Intermittent Insomnia Penderita intermittent insomnia bisa tidur tetapi sering terbangun.

c) Terminal / Matutinal Insomnia Penderita Terminal / Matutinal Insomnia bisa tidur tetapi bangun tidur terlalu pagi, merasa tidak segar dan tidak bisa tidur lagi

d) Compulsive Insomnia Penderita compulsive insomnia takut untuk tidur tetapi penderita juga takut jika tidak tidur

Menurut Erry (2008) ada 3 tipe gangguan insomnia yaitu:

a) Tidak dapat masuk atau sulit tidur disebut juga insomnia inisial dimana pada keadaaan ini sering dijumpai pada orang- orang muda yang mengalami ansietas (kecemasan), berlangsung selama 1-3 jam kemudian karena kelelahan penderita bisa tidur juga

b) Terbangun tengah malam beberapa kali, orang-orang ini dapat masuk tidur dengan mudah tetapi setelah 2-3 jam akan terbangun dan tidur kembali, dan kejadian ini dapat terjadi berulang kali.

c) Terbangun pada waktu pagi yang sangat dini disebut juga insomnia terminal yang manamana orang ini dapat tidur dengan mudah dan cukup nyenyak, akan tetapi pada saat pagi buta sudah terbangun dan tidak dapat tidur lagi, biasanya hal ini terjadi pada orang-orang yang mengalami depresi.

4. Penyebab Insomnia

Schneider yang menjabat sebagai direktur medis di Departement of Psychiatry di CedarsSinai mengatakan bahwa penderita dan ahli jiwa harus berusaha menemukan penyebab yang sebenarnya dari insomnia yang diderita, hal ini ditujukan untuk memperoleh solusi yang terbaik Menurut Budiman, 2009 insomnia disebabkan oleh berbagai faktor yaitu:

a) Faktor Psikogenik

1) Masalah psikis pada seseorang seperti rasa rendah diri, perasaaan disingkirkan, tidak berguna, sampai pada keadaan depresi dapat menimbulkan insomnia.

2) Rasa cemas dan perasaaan takut yang berlebihan dapat pula mengakibatkan kesulitan untuk tidur ataupunh sering kali terbangun dari tidur. Begiti pula dengan mimpi yang tidak menyenangkan dan menakutkan sering kali mengganggu tidur seseorang.

3) Stres kejiwaan yang berhubungan dengan masalah perkawinan, ketidakpuasan dalam pekerjaan, kesulitan adaptasi dengan perubahan kehidupan modern yang sangat cepat, masalah finansial dalam keluarga dan lain sebagainya ikut pula berpengaruh pada gangguan insomnia.

b) Faktor Fisik

1) Bekerja terlampu lama dan keras juga dapat mempengaruhi tidur seseorang 
2) Rasa sakit dan perasaan tidak menyenangkan dapat juga mempengaruhi tidur seseorang

3) Gangguan insomnia sering dijumpai pada masa anak-anak dan masa usia lanjut. Selama tahun pertama dari kehidupan, ketegangan pada masa bayi sering kali menyebabkan gangguan tidur dan gangguan minum. Kecemasan sering kali membangunkan bayi pada malam hari. Penyakit usia lanjut seperti diabetes militus, asma bronkiale, arteriosklerosis, payah ginjal, kesemuanya dapat mengakibatkan insomnia.

c) Faktor kepribadian

Penderita insomnia sering kali terdapat corak kepribadian tertentu, pada tahun 1996 Kales dan kawan-kawan melakukan penelitian dengan "Minessota Multiphasic Personality Inventory" (MMPI), terhadap penderita-penderita yang keluhan utamanya insomnia. $85 \%$ dari pasien insomnia itu ada 1 atau 2 skala MMPI-nya cenderung meningkat kearah patologik dan ditemukan terbanyak adalah depresi kemudian psychastenia,conversion hysteria, psychopathic deviate dan hypochondriasis. Bentukbentuk kepribadian ini akan menyebabkan internalisasi dari gangguan psikologik yang mengakibatkan suatu aktifitas fisiologik dan proses ini merupakan mekanisme psikofisiologik dari insomnia (Budiman, 2009).

\section{B. Progressive Muscle Relaxation}

1. Pengetian

Pengertian progressive muscle relaxation adalah terapi relaksasi dengan gerakan mengencangkan dan melemaskan otot - otot pada beberapa bagian tubuh tertentu yang diberikan pada klien dengan gangguan fisik karena penyakit maupun secara fungsional berupa penurunan aktivitas sehari-hari serta mengalami insomnia. Dalam melakukan terapi ini, klien membedakan sensasi saat otot dalam kondisi tegang dan rileks serta merasakan kenyamanan dan rileksasi saat otot dalam kondisi lemas (Ramdhani \& Putra, 2009)

2. Tujuan Progressive muscle relaxation.

a) Membantu mengurangi tanda dan gejala insomnia seperti menurunkan komsumsi oksigen tubuh, laju metabolisme tubuh, laju pernapasan, ketegangan otot, dan tekanan darah sistolik serta gelombang alpha otak.

b) Meningkatkan beta endorphin

c) Meningkatkan imun seluler.

d) Membantu keterampilan koping dalam mengatasi kecemasan secara aktif

\section{Indikasi}

Menurut Ramdhani \& Putra (2009) terdapat beberapa hal yang menjadi indikasi dalam progressive muscle relaxation yaitu :

a) Managemen stress dan insomnia dengan menurunkan tanda dan gejala insomnia

b) Manajemen nyeri pada gangguan fisik dengan meningkatkan beta endorphin dan berfungsi meningkatkan imun seluler.

c) Manajemen insomnia dengan menurunkan gelombang alpha otak.

\section{Kontra indikasi}

Beberapa hal yang dapat menjadi kontraindikasi latihan progressive muscle relaxation antara lain cedera akut atau ketidaknyamanan musculoskeletal, infeksi atau inflamasi, dan penyakit jantung berat atau akut. Latihan progressive muscle relaxation juga tidak dilakukan pada sisi otot yang sakit.

5. Karakteristik Pasien.

Pasien yang dapat diberikan terapi progressive muscle relaxation pada klien dengan insomnia adalah:

a) Berusia 60 - 74 tahun 
b) Bersedia jadi responden.

c) Klien gangguan fisik yang mengalami gangguan tidur

d) Tidak mengalami penurunan kesadaran.

e) Fungsi pendengaran baik.

f) Tidak mengalami ketidaknyamanan muskuloskeletal seperti, tidak mengalami infeksi atau inflamasi pada muskuloskeletal, tidak mengalami trauma pada leher dan kepala, tidak mengalami penyakit jantung berat dan akut, tidak mengalami fraktur/trauma tulang.

\section{Terapis}

Terapi ini dapat dilakukan oleh perawat yang memiliki keahlian khusus, karena progressive muscle relaxation merupakan terapi yang membutuhkan keterampilan tertentu dan memerlukan komitmen rutin untuk dilakukan.

7. Teknik pelaksanaan progressive muscle relaxation.

Progressive muscle relaxation atau relaksasi otot progresif merupakan kontraksi dan relaksasi berbagai kelompok otot mulai dari kaki kearah atas atau dari kepala kearah bawah. Pelaksanaan terapi ini diberikan 1 kali setiap hari selama 7 hari berturut- turut sehingga total pelaksanaan adalah sebanyak 7 kali. Setiap gerakan yang dilakukan dalam terapi progressive muscle relaxation ini dilakukan sesuai dengan kemampuan klien sehingga klien tidak akan merasakan nyeri pada saat menegangkan otot. Pelaksanaan gerakan progressive muscle relaxation dalam modul ini terdiri dari 14 gerakan seperti yang dikembangkan oleh Ramdhani \& Putra (2009).

Pada pertemuan pertama, terapis melakukan secara langsung gerakan progressive muscle relaxation dengan melakukan role play terlebih dulu dan bimbingan kepada pasien sampai pasien memahami dan mampu melakukan 14 gerakan dalam progressive muscle relaxation ini. Setiap gerakan terdiri dari role model, role play, feed back dan tindak lanjut. Pertemuan kedua sampai keempat, terapis tidak melakukan secara langsung, tetapi pasien mengikuti gerakan terapi dengan panduan CD yang sudah disiapkan oleh terapis. Teknik pelaksanaan progressive muscle relaxation diuraikan pada bab berikutnya.

Pelaksanaan progressive muscle relaxation ini menggunakan area di ruang rawat inap rumah sakit umum dengan klien gangguan fisik yang mengalami ansietas. Terapi ini dilakukan pada ruangan yang nyaman bagi klien maupun perawat dan tidak menganggau klien lain.

\section{Lansia}

1. Definisi Lansia (lanjut usia)

Lanjut usia (lansia) menurut UU Nomor 13 Tahun 1998 tentang Kesejahteraan Lanjut Usia pasal 1 ayat 2 adalah seseorang yang telah mencapai usia enam puluh (60) tahun ke atas (Depkes RI, 2005).

2. Batasan-batasan usia lanjut

Lanjut usia memiliki batasan-batasan yang telah ditetapkan yaitu batasan lanjut usia yang di buat WHO dan Depkes RI. Menurut WHO (World Health Organization) batasan lanjut usia meliputi; a). Usia pertengahan (middle age) ialah kelompok usia 45 sampai 59 tahun, b). Lanjut usia (elderly) = antara 60 dan 74 tahun, c). Lanjut usia tua (old) = antara 75 dan 90 tahun, d). Usia sangat tua (very old) $=$ diatas 90 tahun (Wahjudi Nugroho, 2000).

Sedangkan dalam pengelompokannya menurut Depkes. RI, lanjut usia dibagi menjadi empat bagian. Pertama = umur pertengahan dalam masa virilitas, antara 45-54 tahun. Kedua $=$ lanjut usia dini dalam masa prasenium, usia 55-64 tahun. Ketiga = lanjut usia dalam masa senium, usia 65 tahun ke atas. Keempat = lanjut usia dengan resiko tinggi , usia lebih dari 70 tahun (Depkes RI, 2005).

3. Faktor-Faktor Pemicu Proses Menua

Ada beberapa faktor yang mempengaruhi kecepatan seseorang menjadi tua, baik yang dapat dikendalikan maupun yang tidak dapat dikendalikan antara lain: 
a) Faktor genetika merupakan faktor bawaan (keturunan) yang berbeda pada setiap individu. Faktor inilah yang mempengaruhi perbedaan efek menua pada setiap individu, dapat lebih cepat atau lebih lambat.

b) Faktor lingkungan dan faktor gaya hidup. Faktor ini terkait dengan asupan gizi, kebiasaan merokok, minum alkohol dan kafein.

c) Faktor endogenik. Terkait dengan proses penuaan, yaitu perusakan sel yang berjalan seiring perjalanan waktu. Terjadi perubahan-perubahan pada lansia seperti perubahan struktural dan penurunan fungsional kemampuan (Wirakusumah, 2009).

4. Perubahan Pola Tidur Pada Lansia

Tidur merupakan suatu proses otak yang dibutuhkan oleh seseorang untuk dapat berfungsi dengan baik. Masyarakat awam belum begitu mengenal gangguan tidur sehingga jarang mencari pertolongan. Pendapat yang menyatakan bahwa tidak ada orang yang meninggal karena tidak tidur adalah tidak benar. Beberapa gangguan tidur dapat mengancam jiwa baik secara langsung (misalnya insomnia yang bersifat keturunan dan fatal dan apnea tidur obstruktif) atau secara tidak langsung misalnya kecelakaan akibat gangguan tidur. Di Amerika Serikat, biaya kecelakaan yang berhubungan dengan gangguan tidur per tahun sekitar seratus juta dolar.

Insomnia merupakan gangguan tidur yang paling sering ditemukan. Setiap tahun diperkirakan sekitar 20\%-50\% orang dewasa melaporkan adanya gangguan tidur dan sekitar 17\% mengalami gangguan tidur yang serius. Prevalensi gangguan tidur pada lansia cukup tinggi yaitu sekitar $67 \%$. Walaupun demikian, hanya satu dari delapan kasus yang menyatakan bahwa gangguan tidurnya telah didiagnosis oleh dokter.

Lansia dengan depresi, stroke, penyakit jantung, penyakit paru, diabetes, artritis, atau hipertensi sering melaporkan bahwa kualitas tidurnya buruk dan durasi tidurnya kurang bila dibandingkan dengan lansia yang sehat. Gangguan tidur dapat meningkatkan biaya penyakit secara keseluruhan. Gangguan tidur juga dikenal sebagai penyebab morbiditas yang signifikan. Ada beberapa dampak serius gangguan tidur pada lansia misalnya mengantuk berlebihan di siang hari, gangguan atensi dan memori, mood depresi, sering terjatuh, penggunaan hipnotik yang tidak semestinya, dan penurunan kualitas hidup. Angka kematian, angka sakit jantung dan kanker lebih tinggi pada seseorang yang lama tidurnya lebih dari 9 jam atau kurang dari 6 jam per hari bila dibandingkan dengan seseorang yang lama tidurnya antara 7-8 jam per hari.

Berdasarkan dugaan etiologinya, gangguan tidur dibagi menjadi empat kelompok yaitu, gangguan tidur primer, gangguan tidur akibat gangguan mental lain, gangguan tidur akibat kondisi medik umum, dan gangguan tidur yang diinduksi oleh zat. Gangguan tidur-bangun dapat disebabkan oleh perubahan fisiologis misalnya pada proses penuaan normal. Riwayat tentang masalah tidur, higiene tidur saat ini, riwayat obat yang digunakan, laporan pasangan, catatan tidur, serta polisomnogram malam hari perlu dievaluasi pada lansia yang mengeluh gangguan tidur. Keluhan gangguan tidur yang sering diutarakan oleh lansia yaitu insomnia, gangguan ritme tidur,dan apnea tidur (Irawan, 2009).

\section{Metode Penelitian}

Dalam penelitian ini penulis menggunakan jenis penelitian kuantitatif dengan desain penelitian adalah metode quasi eksperimen dengan pre post test control group, yang bertujuan untuk mengetahui suatu gejala atau pengaruh yang timbul, sebagai akibat dari adanya perlakuan tertentu. Ciri khusus dari penelitian eksperimen adalah adanya percobaan atau trial. Percobaan itu berupa perlakuan atau intervensi terhadap suatu variabel. Dari perlakuan tersebut diharapkan terjadi perubahan atau pengaruh terhadap variabel lain (Notoatmodjo, 2005). Penelitian ini jelas untuk mengetahui bagaimana pengaruh progressive muscle relaxation terhadap insomnia pada lansia pada kelompok perlakuan.

Penelitian ini menggunakan desain eksperimen semu (Quasi experimen) karena 
pengelompokan anggota sampel pada kelompok intervensi dan kelompok kontrol tidak dilakukan dengan random atau acak, tapi dilakukan secara Purposivel Sampling yaitu pengambilan sampel dilakukan dengan mengambil kasus atau responden berdasarkan karakteristik tertentu (Notoatmodjo, 2005). Sedangkan Rancang eksperimen yang digunakan adalah pre post test control group (Notoatmodjo, 2005). dimana pada penelitian ini penulis akan membandingkan hasil observasi pada kelompok perlakuan terhadap suatu kelompok kontrol yang serupa tetapi tidak perlu kelompok yang benar-benar sama.

\section{Hasil Penelitain}

Hasil penelitian diperoleh setelah melalui proses pengolahan data. Pengolahan data dilakukan dengan menggunakan software SPSS. Adapun tahapan yang dilalui dalam pengolahan data yaitu tahapan editing, pemberian kode, memasukkan data, membersihkan data dan menganalisis data. Kedua kelompok dilakukan pre- test dan post- test yang hasilnya dibandingkan. Hasil penelitian ini terdiri dari tiga bagian yang akan diuraikan berikut ini:

1. Proses Pelaksanaan Progressive Muscle Relaxation (PMR)

Pada bagian ini akan dijelaskan tentang pelaksanaan Progressive Muscle Relaxation (PMR) mulai dari persiapan penelitian dengan membina hubungan percaya, melakukan kontrak kegiatan, menjelaskan tujuan penelitian, menandatangani lembar persetujuan penelitian. Pelaksanaan penelitian dimulai dengan melakukan pre tes, pelaksanaan Progressive Muscle Relaxation (PMR) dan terminasi serta post tes. Pelaksanaan Progressive Muscle Relaxation (PMR) dilakukan di Panti Sosial Lanjut Usia Tresna Werdha Natar Provinsi Lampung adalah:

a) Persiapan

Untuk kelompok intervensi dilakukan di Panti Sosial Lanjut Usia Tresna Werdha Natar Provinsi Lampung, mendata pasien insomnia, dengan cra wawancara dan memberikan kuisionner, mengkaji program terapi yang diberikan oleh petugas kesehatan. Kemudian peneliti menghampiri pasien, menyapa berkenalan dengan pasien. Lalu menanyakan cara yang biasa digunakan agar rileks dan tempat yang paling disukai.

Setelah pasien menceritan cara yang sering digunakan maka peneliti menjelaskan tujuan dan prosedur teknik yang lebih tepat yaitu Progressive Muscle Relaxation (PMR). Jika pasien menyetujui maka diberikan infermed concent. Sedangkan untuk kelompok kontrol yang ada di Panti Sosial Lanjut Usia Tresna Werdha Natar Provinsi Lampung, Pre Test dilakukan serempak pada 25 responden pada hari saat peneliti melakukan penelitian.

b) Pelaksanaan

Pada tahap pelaksanaan ini peneliti menjelaskan teknik yang telah dipersiapkan sesuai dengan standar operasional prosedur yang berlaku. Teknik Progressive Muscle Relaxation (PMR) ini dilakukan 1 kali dalam satu hari dalam waktu 7 hari dengan waktu \pm 30 menit. Disaat dalam waktu 7 hari tersebut perawat mengobservasi pasien untuk melakukan Progressive Muscle Relaxation (PMR), Sedang untuk kelompok kontrol di berikan pendidikan kesehatan mengenai cara menurunkan insomnia. Dalam pelaksanaannya peneliti dibantu oleh beberapa teman mahasiswa.

c) Penutupan

Setelah dalam waktu 7 hari selesai, maka perawat mengevaluasi hasil Progressive Muscle Relaxation (PMR) dan memberikan post test kepada pasien yang telah melakukan teknik tersebut. Untuk pasien kontrol diberikan pula post test.setelah selesai perawat menganjurkan pasien untuk mengulangi teknik Progressive Muscle Relaxation (PMR) ini, bila pasien merasakan insomnianya. Dan perawat mengumpulkan hasil yang diperoleh untuk di olah data nya. 
2. Analisa Univariat

a) Jenis Kelamin Responden

Pada penelitian ini sebagian besar lansia yang ada di Panti Sosial Lanjut Usia Tresna Werdha Natar Provinsi Lampung adalah berjenis kelamin perempuan yaitu sebanyak 29 lansia $(58,0 \%)$. Lansia yang berjenis kelamin perempuan lebih banyak ditemukan mengalami insomnia. Hal ini disebabkan karena perempuan banyak berdiam diri, stres kejiwaan yang berhubungan dengan kesulitan beradaptasi dengan lingkungan sekitar,perasaan tidak menyenangkan, masalah finansial, banyak tidur di waktu siang. Sehingga jadwal tidur lansia akan terganggu dan menimbulkan kesulitan jika akan tertidur atau terbangun saat tidur inilah gejala yang disebut dengan insomnia.

b) Pekerjaan Responden

Pada table 4.1 tampak terlihat bahwa sebagian besar lansia yang ada di Panti Sosial Lanjut Usia Tresna Werdha Natar Provinsi Lampung tidak bekerja yaitu sebanyak 36 lansia (72,0\%). Menurut Budiarto (2000), pekerjaan merupakan suatu aktifitas manusia berdasarkan pada suatu keahlian dan pengetahuan yang dimiliki oleh seseorang untuk memenuhi kebutuhan dalam hidupnya. Dengan pekerjaan yang dimilikinya, maka ada beberapa macam pekerjaan seperti : Pekerjaan ahli, Pekerjaan menengah dan pekerjaan kasar. Insomnia yang dialami lansia memang merupakan hal yang harus diatasi. Jika insomnia tidak segera diatasi, maka hal ini akan mempengaruhi aktivitas lansia. Sehingga banyak nya lansia yang yang mengalami insomnia maka banyak pula terlihat lansia yang tidak banyak bekerja dikarenakan adanya masalah tidur lansia tersebut.

3. Analisa Bivariat

a. Intervensi

Pada penelitian ini menunjukkan bahwa pada klien yang mendapat Progressive Muscle Relaxation (PMR) rata-rata mengalami penurunan insomnia sebelum dan sesudah eksperimen sebesar 1,40 menurun secara bermakna (p-value 0,000 < 0,05). Hasil uji statistik dapat disimpulkan ada penurunan yang bermakna rata-rata insomnia lansia dalam pemberian Progressive Muscle Relaxation (PMR) sebelum dengan sesudah mendapat eksperimen ( $\mathrm{p}$ - value $<0,05)$.

Meskipun penurunan dengan 1,40 tersebut bermakna, namun hal tersebut belum maksimal. Hal ini dapat dipengaruhi dengan adanya keterbatasan dalam penelitian seperti kondisi ruangan yang belum maksimal sesuai dengan teknik yang dianjurkan, keterlibatan peserta dalam melakukan teknik relaksasi yang kurang maksimal dan lain nya. Sehingga penurunan insomnia belum maksimal seperti yang diharapkan.

Menurut Erry (2008), Insomnia adalah ketidakmampuan penderita untuk memperoleh jumlah tidur yang diperlukan agar dapat menjalankan fungsi pada siang hari secara efisien(Berrios). Penderita insomnia pada dasarnya hanya punya dua keluhan utama, dimana seseorang sulit masuk tidur dan sulit mempertahankan tidur(Hartmann). Insomnia dapat didefinisikan sebagai suatu keadaan dimana seseorang sulit masuk tidur atau kesulitan mempertahankan tidur dalam kurun waktu tertentu sehingga menimbulkan penderitaan atau gangguan dalam berbagai fungsi sosial, pekerjaan ataupun fungsi-fungsi kehidupan lainnya.

Progressive Muscle Relaxation (PMR) adalah terapi relaksasi dengan gerakan mengencangkan dan melemaskan otot - otot pada beberapa bagian tubuh tertentu yang diberikan pada klien dengan gangguan fisik karena penyakit maupun secara fungsional berupa penurunan aktivitas sehari-hari serta mengalami insomnia. Dalam melakukan terapi ini, klien membedakan sensasi saat otot dalam kondisi tegang dan rileks serta merasakan kenyamanan dan rileksasi saat otot dalam kondisi lemas (Ramdhani \& Putra, 2009).

Berdasarkan hasil penelitian terdahulu yang dilakukan oleh Supriati (2010) yang menyimpulkan bahwa kunci untuk memicu respons relaksasi dengan cara ini adalah untuk mengambil alih dari otot-otot menegang sukarela oleh mereka dan memaksa mereka ke 
dalam keadaan relaksasi. Setelah otot-otot rileks maka komponen lain dari respons relaksasi secara alami akan mengikuti. Otot-otot rileks membutuhkan oksigen lebih sedikit sehingga pola pernapasan lambat dan memperdalam. Jantung tidak perlu mengalahkan begitu cepat untuk membawa oksigen ke otot-otot tegang. Denyut jantung dan penurunan tekanan darah sistolik serta gelombang alpha otak. Insomnia yang dialami lansia memang merupakan hal yang harus diatasi. Hal ini karena lansia harus diusahakan cukup tidur pada malam hari sehingga pada siang hari lansia bisa beraktifitas tanpa ada keluhan yang berarti. Jika insomnia tidak segera diatasi, maka ini akan menimbulkan masalah baru seperti gangguan jantung dan hipertensi. Insomnia bisa diatasi dengan terapi relaksasi dengan gerakan mengencangkan dan melemaskan otot - otot pada beberapa bagian tubuh tertentu dengan tehnik Progressive Muscle Relaxation (PMR). Sehingga lansia dapat membedakan sensasi saat otot dalam kondisi tegang dan rileks serta merasakan kenyamanan dan rileksasi saat otot dalam kondisi lemas. Hal ini dibuktikan dengan adanya penurunan insomnia pada lansia yang diberikan Progressive Muscle Relaxation (PMR) di panti sosial lanjut usia Tresna Werdha Natar Provinsi Lampung.

Hal ini bisa disimpulkan dengan melihat hasil penelitian pada kelompok yang diberikan Progressive Muscle Relaxation (PMR) dimana pada kelompok yang diberikan Progressive Muscle Relaxation (PMR), insomnia lansia mengalami penurunan yang bermakna.

b. Kontrol

Pada data kontrol menunjukkan bahwa pada kelompok yang tidak mendapatkan Progressive Muscle Relaxation (PMR). Rata-rata penurunan insomnia pada kelompok yang tidak mendapatkan Progressive Muscle Relaxation (PMR) sebesar 0,12 meskipun secara statistik menurun, akan tetapi jika dilihat nilai p-value 0,083>0,05 dapat disimpulkan penurunan insomnia tidak bermakna. Hasil uji statistik dapat disimpulkan ada penurunan yang tidak bermakna rata-rata insomnia lansia dalam pemberian Progressive Muscle Relaxation (PMR) pada kelompok yang tidak mendapatkan Progressive Muscle Relaxation (PMR) (p-value > 0,05).

Berdasarkan hasil penelitian terdahulu yang dilakukan oleh Supriati (2010) yang menyimpulkan bahwa kunci untuk memicu respons relaksasi dengan cara ini adalah untuk mengambil alih dari otot-otot menegang sukarela oleh mereka dan memaksa mereka ke dalam keadaan relaksasi. Setelah otot-otot rileks maka komponen lain dari respons relaksasi secara alami akan mengikuti. Otot-otot rileks membutuhkan oksigen lebih sedikit sehingga pola pernapasan lambat dan memperdalam. Jantung tidak perlu mengalahkan begitu cepat untuk membawa oksigen ke otot-otot tegang. Denyut jantung dan penurunan tekanan darah sistolik serta gelombang alpha otak.

Insomnia yang dialami lansia memang merupakan hal yang harus diatasi. Hal ini karena lansia harus diusahakan cukup tidur pada malam hari sehingga pada siang hari lansia bisa beraktifitas tanpa ada keluhan yang berarti. Jika insomnia tidak segera diatasi, maka ini akan menimbulkan masalah baru seperti gangguan jantung dan hipertensi. Insomnia bisa diatasi dengan terapi relaksasi dengan gerakan mengencangkan dan melemaskan otot - otot pada beberapa bagian tubuh tertentu dengan tehnik Progressive Muscle Relaxation (PMR). Sehingga lansia dapat membedakan sensasi saat otot dalam kondisi tegang dan rileks serta merasakan kenyamanan dan rileksasi saat otot dalam kondisi lemas. Hal ini dibuktikan dengan adanya perbedaan pengaruh Progressive Muscle Relaxation (PMR) terhadap insomnia pada lansia di panti sosial lanjut usia Tresna Werdha Natar Provinsi Lampung antara kelompok eksperimen dan kontrol.

Menurut Erry (2008), Insomnia adalah ketidakmampuan penderita untuk memperoleh jumlah tidur yang diperlukan agar dapat menjalankan fungsi pada siang hari secara efisien(Berrios). Penderita insomnia pada dasarnya hanya punya dua keluhan utama, dimana seseorang sulit masuk tidur dan sulit mempertahankan tidur(Hartmann). Insomnia dapat 
didefinisikan sebagai suatu keadaan dimana seseorang sulit masuk tidur atau kesulitan mempertahankan tidur dalam kurun waktu tertentu sehingga menimbulkan penderitaan atau gangguan dalam berbagai fungsi sosial, pekerjaan ataupun fungsi-fungsi kehidupan lainnya.

Progressive Muscle Relaxation (PMR) adalah terapi relaksasi dengan gerakan mengencangkan dan melemaskan otot - otot pada beberapa bagian tubuh tertentu yang diberikan pada klien dengan gangguan fisik karena penyakit maupun secara fungsional berupa penurunan aktivitas sehari-hari serta mengalami insomnia. Dalam melakukan terapi ini, klien membedakan sensasi saat otot dalam kondisi tegang dan rileks serta merasakan kenyamanan dan rileksasi saat otot dalam kondisi lemas (Ramdhani \& Putra, 2009).

Hal ini bisa disimpulkan dengan melihat hasil penelitian antara kelompok yang diberikan Progressive Muscle Relaxation (PMR) dan tidak diberikan Progressive Muscle Relaxation (PMR) dimana pada kelompok yang diberikan Progressive Muscle Relaxation (PMR), insomnia pada lansia mengalami penurunan yang bermakna jika dibandingkan dengan kelompok klien yang tidak mendapatkan Progressive Muscle Relaxation (PMR).

\section{Simpulan dan Saran}

Berdasarkan hasil penelitian dan pembahasan mengenai pengaruh PMR (Progressive Muscle Relaxation) terhadap insomnia pada lansia di panti sosial lanjut usia Tresna Werdha Natar Provinsi Lampung terhadap 50 responden, dapat disimpulkan bahwa :

1. Karakteristik klien :

a. Distribusi frekuensi karakteristik lansia yang mengalami insomnia rata - rata berjenis kelamin perempuan sebesar 58,2\%.

b. Distribusi frekuensi karakteristik lansia yang mengalami insomnia rata - rata tidak bekerja sebesar $72,0 \%$.

2. Tingkat insomnia sebelum lansia mendapatkan progressive muscle relaxation yaitu ratarata sebesar 7,80.

3. Tingkat insomnia sesudah lansia mendapatkan progressive muscle relaxation yaitu rata-rata sebesar 6,40 .

4. Ada perbedaan insomnia antara sebelum dan sesudah lansia mendapatkan progressive muscle relaxation yaitu rata-rata sebesar 1,40. Ada pengaruh pengaruh PMR (Progressive Muscle Relaxation) terhadap insomnia pada lansia di panti sosial lanjut usia Tresna Werdha Natar Provinsi Lampung dengan P Value 0,000 dengan tingkat kepercayaan 0,05 sehingga $\mathrm{P}$ Value $<\alpha(0,000<0,05)$

Saran-saran yang dapat dipertimbangkan berdasarkan hasil penelitian adalah bagi peneliti selanjutnya adalah perlu diadakan penelitian lanjutan dengan memperbaiki keterbatasan penelitian yang ada, menggunakan item kuesioner penelitian yang lebih banyak dan waktu penelitian yang tepat, menggunakan metode penelitian yang tepat.

\section{Daftar Pustaka}

Alexander, 2001, 1, The relationship between low self esteem and psychiatric diagnosis, http://faculty.mckendree.edu/scholars/2001/wilde.htm, diambil 13 maret 2006

Arikunto. (2002). Prosedur Penelitian : Suatu Pendekatan Praktek, Jakarta. Rineka Cipta

Boyd \& Nihart, (1998), Psychiatric Nursing Contemporary Practice, Philadelphia. LippincottRaven

Burns, D. (1988). Terapi Kognitif Pendekatan Baru bagi Penanganan Depresi. Alih Bahasa : Santosa . Jakarta. Erlangga.

Canadian Assciation Psychiatric, 2004, The relationship between low self esteem and 
interpersonal

relationship,

http://www.cpaapc.org/

Publications/Archives/CJP/2004/september/I zgic.asp, diambil 13 maret 2006

Dennis, C.M.,(1997), Self Care Deficit Theory of Nursing : Concepts and Applications, St. Louis. Mosby

Gordon, 1988, If 10, Effects of cognitive therapy on psychological symptoms and social functioning, http://www.insightforwomen.com/w- research.htm : diambil 13 maret 2006

Hastono, (2001), Analisa Data, Fakultas Kesehatan Masyarakat Universitas Indonesia. Tidak dipublikasikan

Hammond, 1990, Low self esteem of psychotherapy patients : a qualitative inquiry, http://www.nova.edu/ssss/QR?QR11- 1/vanzyl.pdf : diambil 21 Maret 2007

Keliat, B. A. (1998). Gangguan Konsep Diri Pada Klien Gangguan Fisik Di Rumah Sakit Umum. Jakarta. Tim Keperawatan Jiwa FIK UI

Keliat, B.A. (2006). Materi Kuliah : Terapi Kognitif.

Mohr, W.K. (2006). Psychiatric Mental Health Nursing. Sixth Editions. Philadelphia: LWW Nanda. (2005). Nursing Diagnoses : Definition \& Classification. Philadelpia: Nanda International.

Panggabean, (2005), Materi kuliah : Pelayanan Kesehatan Jiwa di Sistem Pelayanan Kesehatan. Tidak dipublikasikan.

Sanderson, 2002, General description of cognitive therapy, http://drsanderson.com./cogther.html, diambil 2 April 2007

Sastroasmoro \& Ismael. (2002). Dasar-dasar Metode Penelitian Klinis, ed 2, Jakarta. Sagung Seto

Shives, L.R. (1998). Basic Concept Psychiatric - Mental Health Nursing. Fourth edition. Philadelphia: Lippincolt.

Silverstone \& Salsali, 2003, Low self esteem and psychiatric patients, http://www.annalsgeneralpsychiatry.com/content/2/1/2, diambil 21 Maret 207

Soedarsono, (2007), Materi kuliah : Belajar dan Pembelajaran. Tidak dipublikasikan. 
Stuart \& Laraia. (2005). Principles and Practis of Psychiatric Nursing, St. Louis. Mosby

Suhartini, 2004, http:/www.damandiri.or.id/detail.php?id:340, diperoleh tanggal 4 April 2007

Susanti, (2009). Konseling kelompok dengan pendekatan positive psychology bagi lansia. Jakarta. Unika Atmajaya.

Undang-undang No. 36 tahun 2009 tentang Kesehatan

Videbek, S. (2001). Psychiatric Mental Health Nursing. (9th edition). Philadelphia : Lippincott

Westermeyer, 2005, The cognitive Model of Depression, file:///D:/Data/bdHR/tesis/artikel/cognitive\%20therapy \%20p, diambil tanggal 21 Maret 2007

Wojowasito. (1995).Kamus Besar Bahasa Indonesia, Jakarta. Balai Pustaka

Zyl et all, 2006, General description of cognitive therapy, http://www.nova.edu/ssss/QR?QR11- 1/vanzyl.pdf: diambil 21 Maret 2007 
